\title{
Seed rain across fire-created edges in a Neotropical rainforest
}

Janaine Isabela da Silva Rocha ( $\nabla$ janainerocha@yahoo.com.br )

Universidade Estadual de Santa Cruz https://orcid.org/0000-0002-1651-9689

Gustavo Souza Cruz Menezes

Instituto Chico Mendes de Conservacao da Biodiversidade

Eliana Cazetta

Universidade Estadual de Santa Cruz

Pavel Dodonov

Universidade Federal da Bahia

Daniela Custódio Talora

Universidade Estadual de Santa Cruz

\section{Research Article}

Keywords: post-fire restoration, dispersal, edge influence, forest influence, tropical forest

Posted Date: August 9th, 2021

DOI: https://doi.org/10.21203/rs.3.rs-777032/v1

License: (c) (i) This work is licensed under a Creative Commons Attribution 4.0 International License.

Read Full License 
${ }^{1}$ Department of biological Sciences, Universidade Estadual de Santa Cruz (UESC), Rodovia Ilhéus-Itabuna, Km.

5 16. Ilhéus, Bahia, Brazil. 42662-900;

$6 \quad{ }^{2}$ Chico Mendes Institute for Biodiversity Conservation, Ministry of Environment, Rod. BA 001, km 45, Una, BA, $7 \quad$ Brazil. 45690-000;

$8{ }^{3}$ Institute of Biology, Federal University of Bahia. Rua Barão de Jeremoabo, 668, Ondina, Salvador, Bahia, Brazil. $940170-115$.

*corresponding author: janainerocha@yahoo.com.br

14 Human-induced wildfires are increasing in frequency in tropical forests, and their deleterious consequences for 15 biodiversity include decreases in seed rain, which may be affected directly by fire or indirectly by the creation of edges between forest and non-forest environments. Understanding seed rain is key to assess the potential for natural 17 regeneration in plant communities. We assessed the impact of fire and fire-created edges on seed rain species richness, abundance, size, weight, and dispersal syndromes in Atlantic Forest remnants in Bahia, Brazil. We assessed seed rain at monthly intervals for an entire year along seven $300 \mathrm{~m}$-long transects placed perpendicular to the edge. We installed seed traps at the edge and at 20,40,60,80,100, and $150 \mathrm{~m}$ into the burnt area and into the forest from forest edge. We recorded a total of 9,050 seeds belonging to 250 morphospecies. We did not observe edge influence; however, we detected a lower abundance and proportion of animal-dispersed seeds in the burnt than in the unburnt areas. The seed abundance in the burnt areas was lower and seeds were smaller and lighter than those in the unburnt area. Seed rain in the burnt area was not greater near to the forest than far from it. The abundance and richness of seed rain was positively correlated with tree density. Our findings highlight the lack of seed rain in burnt areas and differences in community composition between the burnt and unburnt areas. Collectively, these results indicate negative consequences on natural regeneration, which can lead to permanent secondarization and challenges for early regeneration of burnt areas, which will initially have impoverished forests

Keywords: post-fire restoration, dispersal; edge influence; forest influence; tropical forest 
34 We are grateful to ICMBio (Chico Mendes Institute for Biodiversity Conservation) for the authorization to carry 35 out the research in the RVS de Una (SISBIO license no. 60990-1), to Adson Santos for his assistance in data 36 collection and to Rafael de Oliveira Xavier and Juliana Silveira dos Santos, and two anonymous reviewers, whose 37 suggestions improved the manuscript, and Caroline Franklin for English reviewing. 
Fires play a significant role in tropical ecosystems by influencing community structure and species composition (Bond and Keeley 2005). In tropical forests, the geographic extent of forests may be limited by fires as well as edaphic and climatic factors (Hoffmann and Moreira 2002; Russell-Smith et al. 2004). Even though evolutionary history resulted in fire-resistant traits for some vegetation types (Hoffmann et al. 2003; Pausas et al. 2006; Maurin et al. 2014), anthropogenic wildfires are an increasing threat to biodiversity. In tropical forests, wildfires used to be rare or absent (Thonicke et al. 2001; Chisholm et al. 2016; Barlow et al. 2020) but have become a recurring disturbance (Armenteras et al. 2013; Granzow de la Cerda et al. 2012) in the last decades. Interactions with other anthropogenic disturbances, such as climate change and deforestation, are changing fire intensity and impacts (Kelly et al. 2020, Driscoll et al. 2021). In tropical rain forests, a single fire can release between 7.7 and 22,3 Mg C ha ${ }^{-1}$, depending on land use history and previous fires (Cochrane et al., 1999; Balch et al., 2008). The increase in the frequency of anthropogenic fires is expected to change forest structure (Cochrane et al., 2004). For example, fires may result in the invasion of Atlantic forest fragments by the bracken fern Pteridium sp., which may become the dominant species above ground and in the seed bank (Silva and Silva-Matos 2006, Menezes et al. 2019).

Wildfires induce different levels of vegetation mortality, creating edges between stands of different 54 structural characteristics according to the burn severity (Parkins 2018) and between burnt and unburnt vegetation. These edges may alter community structure and dynamics, which can consequently cause edge influence (Murcia 1995; Harper et al. 2005). Partial burning of vegetation and organic matter at fire-created edges modifies abiotic attributes such as light, wind, and moisture (Harper et al. 2004; Harper et al. 2005). For example, edges between forest and non-forest vegetation alter wind speed (Laurance and Curran 2008), with possible consequences for seed dispersal by wind (anemochoric seeds; Augsperger and Franson 1987). Finally, such edges may affect animal behavior by attracting animals (positive edge effect) or causing edge avoidance (negative edge effect, Potts et al. 2016). Consequently, fire-created edges may also affect seed dispersal by animals (zoochoric seeds; Freitas et al 2013; Ssali 2018). Thus, seed rain is likely to be affected by forest edges (Capellesso et al. 2018; Vespa et al. 2014) and may consequently impact regeneration processes (Nathan et al. 2002).

Mature forest fragments near fire-affected areas are essential for seed inflow and may act as source areas for restoration (Rodrigues et al. 2009). Closer proximity to undisturbed forest edges may increase the dispersal of some vertebrate species, especially seed-dispersing birds (Casenavea et al. 1995; Ingle 2002). "Forest influence" occurs when a forest fragment affects biotic or abiotic variables in the adjacent disturbed area (Baker et al. 2013). 

edges (Pollock et al. 2017) and consequently seed dispersal to the disturbed areas. Forest influence can thus improve the recolonization and establishment of viable populations in the disturbed area via seed dispersal from the forest edge or from surviving individuals within the burnt area (Baker et al. 2013).

In this study, we explored gradients in seed rain across fire-created edges in the Brazilian Atlantic Forest. Our main objectives were i. to compare seed rain between the burnt and unburnt areas; ii. to evaluate the existence of edge and forest influence on seed rain at fire edges; and iii. to assess whether variation in seed rain can be explained by the structural characteristics of vegetation. We assessed seed rain by evaluating seed abundance and species richness, as well as different dispersal mechanisms. We expected seed rain to differ between the burnt area and the remaining forest and to be affected by edge proximity, with a gradient from higher richness and abundance within the forest interior to lower richness and abundance within the burnt area. We also expected that zoochoric seeds would be more abundant than non-zoochoric seeds in unburnt areas, as previously recorded for tropical forests (Griz and Machado 1998; Jordano and Schupp 2000). We predicted that zoochoric seeds would be larger and heavier in the forest interior (Tabarelli et al. 2010), than in the burnt area, representing edge avoidance by large-bodied frugivores; and that non-zoochoric seeds would be more prevalent in the burnt area than in the intact forest.

\section{Materials and methods} Study area

The study site is in a protected area, the Una Wildlife Refuge (Refúgio de Vida Silvestre de Una - RevisUna) $\left(15^{\circ} 08^{\prime} 15^{\prime \prime} \mathrm{S}, 39^{\circ} 00^{\prime} 39^{\prime \prime} \mathrm{W}\right)$, which is in the municipality of Una in southern Bahia, North-Eastern Brazil. The area is affected by anthropogenic impacts, especially those caused by deforestation for new agriculture fields, poaching, and extraction of wood and other plant products by local dwellers (GSCM, pers. obs.). The Revis-Una is 23,404 ha in size and has a humid to sub-humid climate without a defined dry period, an annual rainfall of 1,600 to $1,800 \mathrm{~mm}$, and an average yearly temperature of $23^{\circ} \mathrm{C}$ (SEI-BA 1998). The soil is yellow oxisols (Santos et al. 2011) with a mostly sandy soil texture (pers. obs). The vegetation is 15 to $30 \mathrm{~m}$ tall and characterized by a large areas, bamboos (Menezes et al. 2019). 
The wildfires in the area are likely a result of the use of fire for management of agricultural areas within and around the Revis-Una, where fire can be used to prepare land for agriculture (Barlow et al. 2019). The area underwent accidental soil and surface fires between December 2015 and February 2016. The duration of each of the fires was approximately one month and the fires impacted different parts of the protected area (Menezes et al. 2019). The wildfires caused profound structural changes in burnt areas, which had lower basal area and density of trees, saplings, lianas and herbaceous life-forms, but higher density of snags, logs (fallen trees) and pioneer species (such as Trema spp., Cecropia spp., Solanum spp.) as well as graminoids, than the surrounding unburnt forest. The bracken fern Pteridium arachnoideum (Kaulf.) Maxon dominated burnt areas, forming fronds with very high height and cover (Menezes et al. 2019). Sampling started approximately a year and a half after the fires ended.

\section{Sampling design}

Within the protected area, we selected three partially burnt forest patches (Fig. 1a). All patches showed a clear edge between the forest and the burnt area (Fig. 1b) and the sizes of the burnt areas were 28, 63.5, and 260 ha. Within these areas, we placed a total of seven transects, at least $100 \mathrm{~m}$ apart from each other, perpendicular to the edge and extending from $150 \mathrm{~m}$ into the forest to $150 \mathrm{~m}$ into the burnt area. Along each transect we installed 13 seed collectors (Fig. 1c): at the edge (determined by the presence of charcoal on the soil) and at 20, 40, 60, 80, 100 and $150 \mathrm{~m}$ into the forest and into the burnt area from the edge. Thus, we used a total of 91 seed traps at the seven transects. They were made of a $1 \mathrm{~m}$ x $1 \mathrm{~m}$ square piece of polyester mesh, with a $1 \mathrm{~mm}$ mesh size, nailed on eight wooden sticks at a height of $1 \mathrm{~m}$ from the ground. This seed trap design is commonly used in seed rain studies (Melo et al, 2006; Rother et al, 2015), especially to capture wind-dispersed seeds and those dispersed by birds, bats and primates, but not seeds dispersed by ground vertebrates or invertebrates. The seed traps were visited monthly from September 2017 to August 2018, and all the material within them was taken to the lab for sorting. Next to each seed collector we placed a $20 \mathrm{~m} \mathrm{x} 4 \mathrm{~m}$ transect (long side parallel to the edge) to sample vegetation structure. In each transect we measured the diameter at breast height (dbh) of all trees and snags with a dbh of at least $10 \mathrm{~cm}$ (detailed results for vegetation structure can be found in Menezes et al. 2019).

\section{Sorting and classification of the collected material}

In the lab, we first separated the fruits and seeds from the plant litter. We photographed the fruits and removed the pulp to store the seeds. We then weighed, measured the width, and took pictures of all seeds, separating them into morphotypes (which we treat here as morphospecies) where each new seed that was different 

dispersal, especially fruits such as drupes or berries and seeds with aril; b) anemochoric: seeds with structures for wind dispersal; and c) autochoric: seeds with explosive mechanisms. For data analysis, we grouped anemochoric and autochoric seeds into a single non-zoochoric category.

Data analysis

We analyzed the following response variables: total seed abundance (number of seeds per trap); average seed species richness (average number of morphospecies per month); total seed species richness (total number of different morphospecies observed at a seed trap throughout the study); average seed width per seed trap; and average seed weight per seed trap. We also calculated seed rain abundance and species richness separately for the dispersal categories (zoochoric and non-zoochoric species). Finally, we used seed width and seed weight as morphological traits important for zoochoric seeds (Moles et al 2005; Moran and Catterall 2010, Todeschini et al 2020) and non-zoochoric seeds (Traveset and Rodríguez-Pérez 2008), respectively. We excluded samples with no seeds for average seed width and average seed weight. In some cases $(0.2 \%$ of the total seeds collected), seed weight was below the detection limit of our scales so we assigned a value of $0.0001 \mathrm{~g}$ to the average weight. created different generalized linear and additive mixed models (Zuur et al. 2009), including transect as a random factor in all models. This analysis enabled us to simultaneously assess the differences between burnt and unburnt areas, the existence of edge-related gradients, and the shape of these gradients when present. Thus, we created six models for each response variable (Fig. 2): 1) a null (intercept-only) model representing the null hypothesis of no difference between the burnt and unburnt areas and no edge or forest influence; 2) a categorical model, with location (burnt area or unburnt forest) as an explanatory variable and with the edge being classified as unburnt forest; 3) a categorical model, with location as an explanatory variable, and with edge being classified as burnt area; 4) an additive model, with distance as an explanatory variable and the response variables modeled as a smooth function of distance; 5) an additive model that also included distance as an explanatory variable, with the edge being classified as unburnt forest; 6 ) an additive model that also included distance as an explanatory variable, with the edge being classified as burnt area. In the additive models, the optimal degree of smoothing was determined by cross-validation (Zuur et al. 2009), but we established a maximum smoothing of 4 effective degrees of freedom to avoid overfitting. 
For count variables (abundance and total seed rain species richness), we used the negative binomial distribution. For average seed rain species richness we used the Gaussian distribution; for average weight and width we used the gamma distribution. We then calculated Akaike's information criterion corrected for small sample size (AICc; Burnham and Anderson 2002) for each model, and, for each response variable, selected the simplest model among those with a $\triangle \mathrm{AICc} \leq 2.0$.

We also compared the mean values of the response variables between burnt and unburnt areas (excluding the collectors located at the edge) by means of a restricted-permutation t-test. The significance of the test was assessed by randomizing the label ("Fire" or "Forest") between the collectors of each transect (Manly 2007). For this test, we first calculated the difference in the mean values between the burnt and unburnt areas, then randomized the data as explained above, and recalculated this difference for the randomized data. We used 9999 permutations in addition to the original data, used the absolute value of the difference between the mean values as the test statistic, and calculated significance as the proportion of absolute differences, which were at least as large as the observed absolute difference. We also used bootstrap to calculate $95 \%$ confidence intervals for the values of the response variables in the burnt area and forest, with 9999 pseudo samples in addition to the original data (Manly 2007). We restricted the bootstrap resampling to always consider the same number of elements from each transect. As above, we removed the collectors located at the edge. We performed a Non-metric Multidimensional Scaling analysis (NMDS) with two dimensions $(\mathrm{k}=2)$ to evaluate differences in species composition among areas (forests, edges and burnt areas). We used presence/absence data and the Bray-Curtis dissimilarity index to perform the ordination based on similarities of species composition. We further performed a PERMANOVA using Bray-Curtis distances and 4999 permutations to assess whether the two areas differed significantly. (Pinheiro et al. 2017), bbmle (Bolker and R Development Core Team 2017), lme4 (Bates et al. 2015), gamm4 (Wood and Sheipl 2020) and vegan (Oksanen et al. 2009). The data and codes are available as supplementary seed abundance and seed rain species richness (average zoochoric and non-zoochoric) and two structural variables: number of live trees $(\mathrm{dbh}>10 \mathrm{~cm})$ and number of snags.

We performed all analyses in R 3.4.4 (R Core Team 2017) with the packages mgcv (Wood 2011), nlme material 1 and 2, respectively.

\section{Results}


We collected a total of 9,050 seeds belonging to 295 morphospecies during the study year (12 months), with 4,404 seeds (191 morphotypes) characterized as animal-dispersed and 4,646 seeds (104 morphotypes) windor self-dispersed (autochoric). Seed abundance was highest in the forest, followed by the burnt area and the edge $\left(0.39,0.19\right.$ and 0.12 seeds. $\mathrm{m}^{-2}$.day ${ }^{-1}$, respectively). Tree abundance increased from the burnt area (958 trees / ha) to the forest $(8,360$ trees/ha). In contrast, snag abundance was greater in the burnt area (449 trees/ha) than in the forest (145 trees / ha).

Average seed width varied from 0.01 to $36.6 \mathrm{~mm}$ (Fig. 3a); 84\% (7598) were classified as small, 15\% 2). independent of distance from edge (Table 1). For the total abundance of non-zoochoric species, the best model was the additive and categorical, but the simpler categorical model had a $\triangle \mathrm{AICc}$ higher than the null model, indicating that performance is similar to that of a more complex alternative (Burnham and Anderson 2002). (1399) as average, $0.5 \%$ (47) as large and only $0.08 \%$ (7) as very large. Of the zoochoric seeds (Fig. 3b), $47 \%$ $(3,564)$ were classified as small, $19 \%(828)$ as average, $0.5 \%(24)$ as large and $0.1 \%(6)$ as very large. Seed average weight varied from below our scales' detection limit of $0.001 \mathrm{~g}$ to $30.47 \mathrm{~g}$, with the largest seed being found 100 $m$ inside the forest from the edge (Fig. 3c-d).

We observed significant differences between burnt and unburnt forest for all response variables, as the null model always presented $\Delta \mathrm{AICc}>6$ (Table 1). Furthermore, the restricted permutations revealed differences between burnt and unburnt area for all variables $(\mathrm{p}<0.02)$. All response variables had higher values in the unburnt forest than in the burnt area (Fig. 3-5). In the forest, independent from edge distance, there were 2.2 times more seeds than in the burnt area (2.4 and 2.1 times for total abundance of zoochoric and non-zoochoric seeds, respectively) (Table 2). Similarly, the average and total seed rain species richness in the forest were on average 2.5 times higher than in the burnt area (3 times for zoochoric and 2 times for non-zoochoric) (Table 2). Seed average weight and seed weight was 1.3 times and 2.7 times, respectively, higher in the forest than in the burnt area (Table

We did not observe evidence of edge influence, as the best model was categorical for all variables

The comparison of two models, one in which edge was classified as forest and the other as burnt area, enabled us to assess to which environment the edge was more similar. The $\triangle \mathrm{AICc}$ between these two models was higher for the null model (Table 1). The seed abundance and average richness at the edge were more similar to the burnt area than the forest, but total richness at the edge was more similar to the forest. These results were consistent for all seeds, whether zoochoric or non-zoochoric (Table 1; Fig. 3 and 4). The mean seed weight and width and 
the mean weight of non-zoochoric seeds at the edge were more similar to the forest than the burnt area, but the mean width of zoochoric seeds was more similar to the burnt area than the forest (Table 1; Fig. 5).

The first two axes of the NMDS had a stress value of 0.20 . The second axis showed a partial separation between the unburnt forest and burnt areas, whereas the group formed by the edge was more widely distributed (Fig. 6). We found a significant result in the PERMANOVA $(\mathrm{p}<0.001)$, confirming the difference in species richness among groups and suggesting that species composition varied by location. The ordering axes of the seed rain species richness matrices segregated the forest areas, then the burnt areas and the edges.

Total seed rain abundance was positively correlated with tree abundance $(\mathrm{r}=0.42, \mathrm{p}<0.001)$. Furthermore, zoochoric and non-zoochoric seed abundance were strongly and positively correlated with live trees abundance $(\mathrm{r}=0.46$ and $\mathrm{r}=0.29, \mathrm{p}<0.001$, respectively). Seed rain species richness was also positively correlated with live tree abundance $(\mathrm{r}=0,56, \mathrm{p}<0.001)$, as well as zoochoric and non-zoochoric seed richness $(\mathrm{r}=0.57$ and $0.48, \mathrm{p}<0.001$, respectively). There was no correlation between seed abundance and richness with snags $(\mathrm{r}=0.10$

\section{Discussion}

Our results highlight a strong contrast in seed rain between intact forest and burnt areas. Seed rain species richness and seed abundance were higher in the forest than in the burnt areas, as well as seed size and width, independent of seed dispersal mode. Contrary to our expectations, we did not find a gradient in seed dispersal via seed rain from the edges to the interior of either the burnt areas or the unburnt forest, regardless of seed dispersal type, seed width or seed weight. Interestingly, abundance and mean richness at edges were more similar to forest than burnt areas, but total richness at the edge was more similar to the burnt area than the forest. Collectively, our results may indicate that seed rain is compromised after fires, which can consequently impair initial natural forest regeneration after burning.

We found a two-fold (or more) decrease in abundance of seeds, both zoochoric and non-zoochoric, in the burnt areas as compared to the unburnt forest. This result is similar to what has been observed in other studies in the Atlantic Forest of southern Bahia (Martini and Santos 2007) and Amazonia (Cury et al. 2020). It is known that fire negatively affects sexual reproduction (and therefore seed production) even in fire-prone environments such as savannas (Dodonov et al. 2018; Hoffmann 1998), and this decrease is expected to be even greater in moist forest. In addition, we found that seed rain abundances (total, zoochoric and non zoochoric) were positively correlated to vegetation structure, indicating that areas with higher tree density also have greater seed rain. This 
correlation reinforces the hypothesis that seed rain is reflecting forest structural changes promoted by fire. In the same burnt areas we investigated, a previous study revealed lower densities and basal areas of trees, saplings and lianas, and also higher values of snag density, snag basal area, and log density than the unburnt contiguous forest areas (Menezes et al. 2019).

Seed rain in the burnt areas was impoverished, with fewer species, large and heavy seeds, and zoochoric seeds as compared to the forest. In fact, the morphospecies composition in the seed rain was different between the burnt and unburnt areas, indicating that generally seeds are not moving among areas. Hence, we can assume that seed rain is sourced from propagules of neighboring trees, with few exchanges between burnt and unburnt areas. Previous studies have revealed that forest interior areas had more median and large seeds than forest edges (Melo et al. 2006; Piotto et al. 2019), which may be due to the autochthonous seed rain, representing the species found at each site. This probably occurs because the local composition of the vegetation may indicate the composition of the seed rain (Drake 1998; Jensen 1998), as most seeds fall near the parent plants (Burrows 1994). The few trees that were present in burnt areas produced many small seeds, which is characteristic of pioneer species (Levey 1988) that were responsible for most seed rain abundance.

The forest environments also had higher and heavier seeds than in the burnt area, generally related to zoochoric dispersal. In general, higher and heavier seeds are characteristic of late-successional plant species of the forest interior (Ehrlen and Lehtila 2002) and their dispersal might depend on forest specialist frugivores. Our observation of large seeds exclusively in the forest interior suggests there was low mobility of large seeds to the burnt area, indicating that larger-body frugivores tend to avoid open areas (Guariguata and Pinard 1998). The possible lack of large dispersers may have also hindered the dispersal of these seeds beyond the forest edge (Galetti and Dirzo 2013; Tabarelli et al. 2004); however, the use of burnt areas by dispersers should be tested in future studies.

272 (sugarcane and commercial tree plantations, respectively). Thus, the lack of edge gradients observed in our study

The lack of a gradient in seed rain from the edge to the forest interior was not expected, but followed the structural patterns found in the same areas (Menezes et al. 2019). This result differs from other studies that indicated edge influence on seed rain in the Atlantic Forest (Melo et al. 2006; Vespa et al. 2014); however, contrary 274 increased tree mortality (Laurance 2000; Menezes et al. 2019), that can significantly reduce local seed production (Benítez-Malvido and Martínez-Ramos 2003), may not have manifested yet. Thus, it is possible that stronger 
gradients from the edge into the unburnt forests will be observed as the edge develops because edge influence

277 often changes with time (Chabrerie et al. 2013; Harper et al. 2005). Conversely, the opposite may occur, with the

278 forest and burnt area becoming more similar as the burnt area recovers from the disturbance. The absence of

279 gradients within the burnt area may also be explained by avoidance of the burnt area by seed dispersers or from a

280 lower flux of abiotic dispersed seeds from the forest to the burnt area because the strength of the winds within the

281 forests is generally low. Forest structure affects wind flow, and dispersal distances in forests are considerably

282 shorter than in open areas (Nathan et al. 2002, Vespa et al. 2018).

Even though we observed significantly more seeds in unburnt than burnt forests, our results showed that

284 a relatively large number of seeds also reached the burnt areas, but they were mainly small and light, typically from pioneer species. This may be due to drastic structural change in the burnt areas, the presence of surviving trees post- fire, and post-fire regeneration of some pioneer and fast-growing species, such as Miconia mirabilis, Trema micranta, Cecropia sp, Solanum crinitum and Henriettea succosa thatwere found throughout the burnt area (Menezes et al. 2019). These species are common in burnt areas and favored by disturbances such as fire because they are adapted to secondary forests and edges (Barlow and Peres 2004) and are present in early successional stages after fire (Martini and Santos 2007). They are characterized by high seed production and seeds dispersed by common generalist frugivorous species, such as bats or small birds (Laurance 2007), or wind (Whitmore 1983). The surviving trees can also provide shelter for the dispersing fauna and natural perches, which contribute to seed dispersal beneath tree canopies (Holl 2002). The NMDS results corroborate this idea as they indicate that morphospecies from seed rain have distinct composition in unburnt and burnt areas. These shifts in species composition can converge towards early successional communities (Berenguer et al. 2018) that can become functionally more similar to secondary forests over time (Arroyo-Rodríguez et al. 2017; Howe, 2016), especially if wildfires become more frequent.

Our findings reveal that edges were more similar to forests concerning abundance and mean richness but were more similar to the burnt area for total seed rain species richness. We previously discussed the lack of edge gradient; however, we cannot exclude possible effects when distance to edge is equal to zero. Therefore, effects might be present very close to the edge and did not penetrate into the forest. Indeed, short-distance edge effects, limited to the first meters from the edge or even to the immediate edge, are not uncommon (Dodonov et al. 2013; Harper et al. 2005) and have been observed for some characteristics of vegetation structure at our study site (Menezes et al. 2019). In our study, such edge effects limited to the immediate edge were observed for total seed 
abundance, average seed rain species richness, and the mean width of zoochoric seeds, which may indicate that seed-dispersing fauna avoid the immediate edge as well as the burnt area.

\section{Conclusion}

In our study, seed rain was dominated by small and zoochoric seeds and was not affected by edge influence. We observed differences in abundance, richness and seed dispersal syndromes between the forest and burnt areas. Our results indicate a decrease in large-seeded species and increase of small-seeded species in the burnt areas, which can impair or retard plant recruitment and restoration processes. Importantly, seed rain was not greater near remaining forest patches; instead, the decrease in seed rain was homogeneous throughout the burnt areas. Because forest fire disturbance reduces plant diversity, it compromises future forest regeneration, thus regeneration from seed rain to a burnt area may be less diverse. The decrease in seed diversity is of particular concern because trees are the major component of the diversity, structure, and function of tropical rain forests (Denslow 1987). year of observation so we did not consider possible intra-annual variation in seed rain. Furthermore, our sampling occurred a few years after fire, thus, our results are related to the early regeneration process and could differ with increased time-since-fire. Following the natural successional pathways, the prevalence of small seeds typically from pioneer species found in our study area would be expected during this successional stage (Chazdon 2014). However, it is important to consider the underrepresentation of large seeds in the study area because it suggests that initial regeneration can be impoverished with mostly small seeds of few species. Fires are an ever-increasing

Declarations

This study was funded by the Rectorate for Research and Post-Graduation of the State University of Santa Cruz UESC (PROPP - project number 00220.1100.1773). We received financial support from Idea Wild for essential field equipment. JISR received a Masters scholarship from the Fundação de Amparo à Pesquisa do Estado da Bahia 

nação de Aperfeiçoamento de Pessoal de Nível Superior - Brasil (CAPES) - PNPD. EC thanks the CNPq for the

336 productivity fellowship (306373/2018-1).

$339 \quad$ No conflict to declare.

Code availability

Not applicable

All authors contributed to the study conception. Material preparation, data collection and analysis were performed by J.I.S. Rocha, P. Dodonov and D.C.Talora. The first draft of the manuscript was written by J.I.S.Rocha, and all authors contributed on all versions, reading and approving the manuscript.

\section{References}

Aizen MA, Feinsinger P (1994) Forest fragmentation, pollination, and plant reproduction in a Chaco dry forest, Argentina. Ecology 75:330-351

Armenteras D, González TM, Retana J (2013) Forest fragmentation and edge influence on fire occurrence and intensity under different management types in Amazon forests. Biol Conserv 159:73-79. https://doi.org/10.1016/j.biocon.2012.10.026

Arroyo-Rodríguez, V., Melo, F. P. L., Martínez-Ramos, M., Bongers, F.,Chazdon, R. L., Meave, J. A., ... Tabarelli, M. (2017). Multiple successional pathways in human-modified tropical landscapes: New insights from forest succession, forest fragmentation and landscape ecology research. Biological Reviews, 92(1), 326-340.

Augsperger C, Franson S (1987) Wind dispersal of artificial fruits varying in mass, area and morphology. Ecology $68: 27-42$

Baker SC, Spies TA, Wardlaw TJ, Balmer J Franklin JF, Jordan GJ (2013) The harvested side of edges: Effect of retained forests on the re-establishment of biodiversity in adjacent harvested areas. For Ecol Manag 302:107-121

Balch JK, Nepstad, DC, Brando PM, Curran L, Portela O, Carvalho and Febvre P (2008) Negative fire feedback in a transitional forest of southeastern Amazonia. Global Change Biology 14, 2276-2287, doi: 10.1111/j.13652486.2008.01655.x

Barlow J, Peres CA (2004) Avifaunal responses to single and recurrent wildfires in Amazonian forests. Ecol Appl $14: 1358-1373$ 

ness in Amazonia. Conserv Biol 17:389-400. https://doi.org/10.1046/j.1523-1739.2003.01120.x

Berenguer, E., Gardner, T. A., Ferreira, J., Aragão, L. E. O. C., Mac Nally, R., Thomson, J. R., ... Barlow, J. (2018). Seeing the woods through the saplings: Using wood density to assess the recovery of humanmodified Amazonian forests. Journal of Ecology, 106(6), 2190-2203.

Bolker B and R Development Core Team (2017) bbmle: Tools for General Maximum Likelihood Estimation. R package version 1.0.20

Bond WJ, and Keeley JE (2005) Fire as a global 'herbivore': the ecology and evolution of flammable ecosystems. Trends in Ecology \& Evolution20 7: 387-394.https://doi.org/10.1016/j.tree.2005.04.025

Burnham KP, Anderson DR (2004) Multimodel Inference: Understanding AIC and BIC in Model Selection. Sociol Methods Res. https://doi.org/10.1177/0049124104268644

Burrows CJ (1994) Seed trapping in Ahuriri Summit Bush Scenic Reserve, Port Hills, western Banks Peninsula, 1985- 86. N Z J Bot 32:183-215. https://doi.org/10.1080/0028825X.1994.10410367

Capellesso ES, Scrovonski KL, Zanin EM, Sausen TL (2018) Relação entre chuva de sementes e estrutura florestal em remanescentes de Floresta Atlântica no Sul do Brasil. Iheringia 73:1-181

Casenavea JL, Pelotto JP, Protomastro J (1995) Edge-interior differences in vegetation structure and composition in a Chaco semi-arid forest, Argentina. For Ecol Manag 72:6 1-69

Chabrerie O, Jamoneau A, Gallet-Moron E, Decocq G (2013) Maturation of forest edges is constrained by neighbouring agricultural land management. J Veg Sci 24:58-69

Chazdon RL (2014) Second Growth: The Promise of Tropical Rain Forest Regeneration in the Age of Deforestation. University of Chicago Press, Chicago, IL, U.S.A., 472

Cochrane M and Schulze MD (1999) Fire as a Recurrent Event in Tropical Forests of the Eastern Amazon: Effects on Forest Structure, Biomass, and Species Composition. Biotropica 31(1): 2-166

Cochrane M, Skole DL, Matricardi EAT, Barber C, Chomentowski WH (2004) Selective logging, forest fragmentation, and fire disturbance. In: Working Forests in the Neotropics: Conservation through Sustainable Management? (eds DJ Zarin, JRR Alavalapati, FE Putz, M Schmink), pp. 310-324. Columbia University Press, New York.

Chisholm RA, Wijedasa LS, Swinfield T (2016) The need for long-term remedies for Indonesia's forest fires. Conserv. Biol. 30, 5-6. doi: 10.1111/cobi.12662; pmid: 26612785

Cury RT dos S, Montibeller-Santos C, Balch JK, Brando P, Mand Torezan JMD (2020) Effects of Fire Frequency on Seed Sources and Regeneration in Southeastern Amazonia. Front For Glob Change. https://doi.org/10.3389/ffgc.2020.00082

Denslow JS (1987) Tropical rain forest gaps and tree species diversity. Ann Rev Ecol Syst 18:432-452. https://doi.org/10.1146/annurev.es.18.110187.002243

Dodonov P, Harper KA, Silva-Matos DM (2013) The role of edge contrast and forest structure in edge influence: vegetation and microclimate in the Brazilian cerrado. Plant Ecology 214:1345-1359

Dodonov P, Menezes GSC, Caitano B, Cazetta E, Mielke MS (2019) Air and soil temperature across fire-created edges in a Neotropical rainforest. Agric For Meteorol 276-277: 107606 

9:103-112

Driscoll DA, Armenteras D, Bennett AF, Brotons L, Clarke MF, Doherty TS, Haslem A, Kelly LT, Sato CF, Sitters H, Aquilué N, Bell K, Chadid M, Duane A, Meza-Elizalde MC, Giljohann KM, González TM, Jambhekar R, Lazzari J, Morán-Ordóñez A, Wevill T 2021 How fire interacts with habitat loss and fragmentation. Biol Rev 96: 976-998.

Ehrlen J, Lehtila K (2002) How perennial are perennial plants? Oikos 98:308-322

Freitas CG, Dambros C, Camargo JLC (2013) Changes in seed rain across Atlantic Forest fragments in Northeast Brazil. Acta Oecologica 53:49-55

Galetti M, Dirzo R (2013) Ecological and evolutionary consequences of living in a defaunated world. Biol Conserv $1-6$

Ganade G. Forest restoration in abandoned pastures of Central Amazonia. In: Bierregaard RO, Gascon C, Lovejoy TE, Mesquita RCG (eds). Lessons from Amazonia. The ecology and conservation of a fragmented forest. Yale University Press, New Haven. 2001; pp 313-324.

Granzow-de-la-Cerda Í, Lloret F, Ruiz JE, Vandermeer JH (2012) Tree mortality following ENSO-associated fires and drought in lowland rain forests of Eastern Nicaragua. For Ecol Manag 265:248- 257

Grime JP (2002) Plant Strategies, Vegetation Process and Ecosystem Properties. Wiley, England

Griz LMS, Machado ICS (1998) Aspectos morfológicos e síndromes de dispersão de frutos e sementes na Reserva Ecológica de Dois Irmãos. In: Machado IC, Lopes AV, Pôrto KC (ed) Reserva Ecológica de Dois Irmãos: Estudos em um Remanescente de Mata Atlântica em área urbana. Editora Universitária da Universidade Federal de Pernambuco, Recife, pp 197-224

Guariguata MR, Pinard MA (1998) Ecological knowledge of regeneration from seed in neotropical forest trees: implications for natural forest management. For Ecol Manag 112:87-89

Harper KA, Lesieur D, Bergeron Y, Drapeau P (2004) Forest structure and composition at young fire and cut edges in black spruce boreal forest. Can J For Res 34:289-302

Harper KA, Macdonald SE, Burton PJ, Chen J, Brosofske KD, Saunders SC, Esseen PA (2005) Edge influence on forest structure and composition in fragmented landscapes. Conserv Biol 19:768-782

Hoffmann WA (1998) Post-burn reproduction of woody plants in a neotropical savanna: the relative importance of sexual and vegetative reproduction. J Appl Ecol 35:422-433

Hoffmann WA and Moreira AG (2002) The role of fire in population dynamics of woody plants. The Cerrados of Brazil: Ecology and Natural History of a Neotropical Savanna (eds P.S. Oliveira \& R.J. Marquis), pp. 159- 177. Columbia University Press, New York

Hoffmann WA, Orthen B, Nascimento PKV 2003 Comparative fire ecology of tropical savanna and forest trees. Funct Ecol 17: 720-726.

Holl KD (2002) Long-term vegetation recovery on reclaimed coal surface mines in the eastern USA. J Appl Ecol 39:960-970

Howe, H. F. (2016). Making dispersal syndromes and networks useful in tropical conservation and restoration. Global Ecology and Conservation, 6, 152-178. https ://doi.org/10.1016/j.gecco.2016.03.002

Ingle NR (2002) Seed dispersal by wind, birds, and bats between Philippine montane rainforest and successional vegetation. Oecologia 134:251-261

Jardim AVF, Batalha MA (2009) Dispersal syndromes related to edge distance in cerrado sensu stricto fragments of Central-Western Brazil. Braz Arch Biol Technol 52:1167-1177

Jensen K (1998) Species composition of soil seed bank and seed rain of abandoned wet meadows and their relations to aboveground vegetation. Flora 193:345-359 
Jordano J, Schupp EW (2000) Seed disperser effectiveness: the quantity component and patterns of seed rain for Prunus mahaleb. Ecol Monogr 591-615

459 Keenan RJ, Kimmins JP (1993) The ecological effects of clear-cutting. Environ Rev 1:121-144

460 Kelly et al., (2020) Fire and biodiversity in the Anthropocene. Science 370

461 Laurence WF (2000) Do edge effects occur over large spatial scales? Trends Ecol Evol 15:234-235

462 Laurance WF (2007) Have we overstated the tropical biodiversity crisis? Trends Ecol Evol 22:65-70

463 Laurance WF, Curran TJ (2008) Impacts of wind disturbance on fragmented tropical forests: A review and 464 synthesis. Austral Ecol 33:399-408

465 Levey DJ (2005) Effects of Landscape Corridors on Seed Dispersal by Birds. Science 309:146-148

Manly, B.F.J., 2007. Randomization, Bootstrap, and Monte Carlo Methods in Biology, third ed. Chapman and Hall, Boca Raton, FL.

Martini AMZ, Santos FAM (2007) Effects of distinct types of disturbance on seed rain in the Atlantic forest of NE Brazil. Plant Ecology 190:81-95

Maurin O, Davies TJ, Burrows JE, Daru BH, Yessoufou K, Muasya AM, Bank M, Bond WJ 2014 Savanna fire and the origins of the "underground forests" of Africa. New Phytol 204:201-214.

Meggers BJ (1994) Archeological evidence for the impact of mega-Niño events on Amazonia during the past two millennia. Clim Change 28: 321-338

Melo FPL, Dirzo R, Tabarelli M (2006) Biased seed rain in forest edges: evidence from the Brazilian Atlantic Forest. Biol Conserv 132:50-60

Menezes GSC, Cazetta E, Dodonov P (2019) Vegetation structure across fire edges in a Neotropical rain forest. For Ecol Manag 453: 17587

Menke S, Böhning-Gaese K, Schleuning M (2012) Plant-frugivore networks are less specialized and more robust at forest-farmland edges than in the interior of a tropical forest. Oikos 121:1553-1566

Moran C, Catterall CP (2010) Can functional traits predict ecological interactions? A case study using rain forest frugivores and plants in Australia. Biotropica 42: 318-326

Moles AT, Ackerly DD, Webb CO, Tweddle JC, Dickie JB, Pitman AJ, et al. (2005) Factors that shape seed mass evolution. PNAS 102: 10540-10544. pmid:16030149

Murcia C (1995) Edge effects in fragmented forests: implications for conservation. Trends Ecol Evol 10:58-62

Nathan R, Horn HS, Chave J, Levin SA (2002) Mechanistic models for tree seed dispersal by wind in dense forests and open landscapes. In: Levey DJ et al (ed) Seed dispersal and frugivory: ecology, evolution and conservation. $\mathrm{CAB}$ International, Princeton, pp 69-82

Oksanen J et al. (2009) Vegan: community ecology package. R package version, v1 p 8-8

Parkins K, York A, Di Stefano J (2018) Edge effects in fire-prone landscapes: Ecological importance and implications for fauna. Ecol Evol 8, 5937-5948. https://doi.org/10.1002/ece3.4076

Pausas JG, Keeley JE, Verdú M 2006 Inferring differential evolutionary processes of plant persistence traits in Northern Hemisphere Mediterranean fire-prone ecosystems. J Ecol 94: 31-39.

Pietro-Souza W, Silva NM, Campos EP (2013) Chuva de sementes em remanescentes florestais de campo verde, MT. Revista Árvore 4:689-698

Pinheiro J, Bates D, DebRoy S, Sarkar D and R Core Team (2017) nlme: Linear and Nonlinear Mixed Effects Models. R package version 3.1-131

Piotto D, Craven D, Montagnini F, Ashton M, Oliver C, ThomasWW (2019) Successional, spatial, and seasonal changes in seed rain in the Atlantic forest of southern Bahia, Brazil. PLoS ONE 14: e0226474 
Pollock SZ, Nielsen SE, St. Clair CC (2017) A railway increases the abundance and accelerates the phenology of bear-attracting plants in a forested, mountain park. Ecosphere 8: e01985

Potts JR, Hillen T, Lewis MA (2016) The "edge effect" phenomenon: deriving population abundance patterns from individual animal movement decisions. Theor Ecol 9:233-247 DOI 10.1007/s12080-015-0283-7

R Core Team (2017) R: A language and environment for statistical computing. R Foundation for Statistical Computing, Vienna, Austria. URL https://www.R-project.org/

Rodrigues RR, Lima RAF, Gandolfi S, Nave AG (2009) On the restoration of high diversity forests: 30 years of experience in the Brazilian Atlantic Forest. Biol Conserv 142:1242-1251

Rother DC, Pizo MA, Siqueira T, Rodrigues RR, Jordano P (2015) Community-Wide Spatial and Temporal Discordances of Seed-Seedling Shadows in a Tropical Rainforest. PLoS ONE 10(4): e0123346. doi:10.1371/journal.pone. 0123346

Ries L, Fletcher RJ Jr, Batin J, Sisk TD (2004) Ecological responses to habitat edges: Mechanisms, models, and variability explained. Ann Rev Ecol, Evo Syst 5:491-522

Ries L, Sisk TD (2004) A predictive model of edge effects. Ecology 85:2917-2926

Russell-Smith J, Yates CP, Edwards A, et al. 2003b. Contemporary fire regimes of northern Australia: change since Aboriginal occupancy, challenges for sustainable management. Int J Wildland Fire 12: 283-97

Santos HG, Carvalho Junior W, Dart RO, Aglio MLD, Sousa JS, Pares JG, Fontana A, Martins ALS, Oliveira AP (2011) O novo mapa de solos do Brasil: legenda atualizada. Embrapa Solos 67:1517-2627

\section{SEI (1998) Atributos Climáticos do Estado da Bahia. https://www.sei.ba.gov.br/. Accessed 03 June 2017}

Silva USR, Silva-Matos DM 2006 The invasion of Pteridium aquilinum and the impoverishment of the seed bank in fire prone areas on Brazilian Atlantic Forest. Biodivers Conserv 15:3035-3043.

Silva JMC, Tabarelli M (2000) Tree species impoverishment and the future flora of the Atlantic Forest of northeast Brazil. Nature 404:72-74

Ssali F, Moe SR, Sheil D (2018) Tree seed rain and seed removal, but not the seed bank, impede forest recovery in bracken (Pteridium aquilinum (L.) Kuhn)-dominated clearings in the African highlands. Ecol Evol 8:4224-4236

Tabarelli M, Peres CA (2002) Abiotic and vertebrate seed dispersal in the Brazilian Atlantic forest: implications for forest regeneration. Biol Conserv 106, 165-176

Tabarelli M, Silva JMC, Gascon C (2004) Forest fragmentation, synergisms and the impoverishment of neotropical forests. Biodivers Conserv 13:1419-1425

Tabarelli M, Venceslau Aguiar A, Ribeiro MC, Metzger JP, Peres CA (2010) Prospects for biodiversity conservation in the Atlantic Forest: Lessons from aging human-modified landscapes. Biol Conserv 143:2328-2340

Thonicke K, Venevsky S, Sitch S, Cramer W (2001) The role of fire disturbance for global vegetation dynamics: coupling fire into a Dynamic Global Vegetation Model. Glob Ecol Biogeogr 10:661-677

Todeschini F. Toledo JJL, Rosalino M, Hilário RR (2020) Niche differentiation mechanisms among canopy frugivores and zoochoric trees in the northeastern extreme of the Amazon. Acta Amazonica 50: 263-272.

Traveset A and Rodríguez-Pérez J (2008) Seed Dispersal. Encyclopedia of Ecology 3188-3194. doi:10.1016/b978008045405-4.00860-0

Uhl C, Clark K, Maurino P (1988) Vegetation dynamics in Amazonian treefall gaps. Ecology 751 - 763

Van der Pijl, L (1972) Principles of Dispersal in Higher Plants. Springer-Verlag, Berlin

Vespa NI, Zurita GA, Bellocq MI (2014) Functional responses to edge effects: Seed dispersal in the southern Atlantic Forest, Argentina. For Ecol Manag 328:310-318 
542 Vespa NI, Zurita GA, Gatti MG, Bellocq MI (2018) Seed movement between the native forest and monoculture 543 tree plantations in the southern Atlantic forest: A functional approach. For Ecol Manag 430:126-133

544 Zuur AF, Ieno EN, Walker NJ, Saveliev AA, Smith GM (2009) Mixed Effects Models and Extensions in Ecology 545 with R. Statistics for Biology and Health, New York

546 Whitmore TC (1983) Secondary succession from seed in tropical rain forests. For Abstr 44:767-779

547 Wood SN (2011) Fast stable restricted maximum likelihood and marginal likelihood estimation of semiparametric 548 generalized linear models. J R Stat Soc 73:3-36

549 Wood S, Sheipl F (2020) gamm4: generalized additive mixed models using 'mgcv' and 'lme4'. R package version $550 \quad 0.2-6$

551 Yao J, Holt RD, Rich PM, Marshall WS (1999) Woody plant colonization in an experimentally fragmented 552 landscape. Ecography 22:715-728 
Table 1. Model selection results showing the differences in the corrected Akaike's information criterion ( $\triangle \mathrm{AICc})$

554 values for each model for each response variable.

\begin{tabular}{|c|c|c|c|c|c|c|}
\hline & & & & Model & & \\
\hline & Null & $\begin{array}{c}\text { Categoric - } \\
\text { edge as } \\
\text { forest }\end{array}$ & $\begin{array}{l}\text { Categoric - } \\
\text { edge as fire }\end{array}$ & Gradient & $\begin{array}{l}\text { Gradient and } \\
\text { categoric - edge } \\
\text { as forest }\end{array}$ & $\begin{array}{l}\text { Gradient and } \\
\text { categoric - edge } \\
\text { as fire }\end{array}$ \\
\hline Total abundance & 20.36 & 6.77 & $0.00 *$ & 16.11 & 11.25 & 3.43 \\
\hline $\begin{array}{c}\text { Total abundance - } \\
\text { zoochoric }\end{array}$ & 13.90 & 4.11 & $0.00 *$ & 8.71 & 8.08 & 4.51 \\
\hline $\begin{array}{l}\text { Total abundance - } \\
\text { non-zoochoric }\end{array}$ & 16.62 & 6.90 & $0.68 *$ & 16.82 & 9.59 & 0.00 \\
\hline $\begin{array}{l}\text { Average seed rain } \\
\text { species richness }\end{array}$ & 44.06 & 6.54 & $0.00 *$ & 14.21 & 10.57 & 4.53 \\
\hline $\begin{array}{l}\text { Average seed rain } \\
\text { species richness - } \\
\text { zoochoric }\end{array}$ & 50.94 & 8.59 & $0.00 *$ & 10.26 & 7.74 & 2.04 \\
\hline $\begin{array}{l}\text { Average seed rain } \\
\text { species richness - } \\
\text { non-zoochoric }\end{array}$ & 17.90 & 2.53 & $0.00 *$ & 14.71 & 5.33 & 1.39 \\
\hline $\begin{array}{c}\text { Total seed rain } \\
\text { species richness }\end{array}$ & 46.34 & $0.00 *$ & 6.29 & 24.72 & 4.24 & 9.49 \\
\hline $\begin{array}{l}\text { Total seed rain } \\
\text { species richness - } \\
\text { zoochoric }\end{array}$ & 47.74 & $0.00 *$ & 4.71 & 23.23 & 2.45 & 5.86 \\
\hline $\begin{array}{l}\text { Total seed rain } \\
\text { speciesrichness- } \\
\text { non-zoochoric }\end{array}$ & 29.76 & $0.00^{*}$ & 4.74 & 16.80 & 3.86 & 9.19 \\
\hline Mean width & 8.86 & $0.00 *$ & 2.44 & 3.10 & 3.86 & 5.14 \\
\hline Mean weight & 15.28 & $0.00 *$ & 9.35 & 9.70 & 4.54 & 11.75 \\
\hline $\begin{array}{l}\text { Mean width - } \\
\text { zoochoric }\end{array}$ & 6.40 & 3.01 & $0.00 *$ & 4.90 & 6.81 & 4.59 \\
\hline $\begin{array}{l}\text { Mean weight - } \\
\text { non-zoochoric }\end{array}$ & 12.67 & $0.00 *$ & 10.06 & 5.36 & 2.77 & NA \\
\hline
\end{tabular}

$555 *$ Model selected for each response variable corresponding to the model with the lowest AICc. 
Table 2. Mean values and 95\% confidence intervals (calculated by restricted bootstrap with 9999 random samples plus the original data) for the fire and forest seed collectors and the statistical of this difference (assessed by a restricted randomizations t-test, with 9999 randomizations plus the original data).

\begin{abstract}
Total abundance
Total abundance zoochoric

Total abundance non-zoochoric

Average seed rain species richness

Average seed rain species richness -
\end{abstract} zoochoric

Average seed rain species richness non-zoochoric

Total seed rain species richness

Total seed rain species richness zoochoric

Total seed rain species richnessnon-zoochoric

Mean width

Mean weight

Mean width zoochoric

Mean weight - nonzoochoric

\section{Mean (and confidence interval) - burnt area}

$64.2(44.3-84.7)$

$29.4(18.1-42.8)$

$34.8(23.4-47.8)$

$0.9(0.7-1.2)$

$0.5(0.4-0.6)$

$0.5(0.4-0.6)$

$7.6(6.2-8.9)$

$4.1(3.2-4.9)$

$3.5(2.9-4.2)$

$3.3(3-3.7)$

$0.03(0.02-0.05)$

$4.1(3.5-4.8)$

$0.009(0.005-0.015)$
Mean (and confidence
interval) - unburnt forest

143.7 (115.1 - 174.7)

$71.7(55.5-90.8)$

$72(49-99.2)$

$2.4(2.2-2.6)$

$1.4(1.3-1.6)$

$0.9(0.8-1.1)$

$19.7(18.4-21.2)$

$12.6(11.5-13.7)$

$7.1(6.4-7.9)$

$4.2(3.9-4.5)$

$0.08(0.06-0.10)$

$5.1(4.7-5.5)$

$0.028(0.017-0.042)$
Significance of the difference

0.0006

0.0004

0.0139

0.0001

0.0001

0.0001

0.0001

0.0001

0.0001

0.0018

0.0004

0.0156

0.0013 
Fig. 1 Map of the study area depicting the three partially burnt patches within the Una Wildlife Refuge in southern Bahia, Brazil

Fig. 2 Description and graphical visualization of the six models adjusted for each response variable. Although in this figure the values for all (except the null) models are lower in the burnt area, the models could also show the

571 opposite pattern. The horizontal axes represent distance along the transects, with the burnt area on the left; the vertical lines represent the edge; the solid lines are the expected values for each model and the dashed lines are the

$573 \quad$ confidence intervals

574 Fig. 3 Seed rain showing the average number of seeds (a), average weight of seeds (b), and average width of seeds

575 (c) recorded in each survey in burnt and forest areas in the Atlantic Forest from Brazil. Surveys were performed monthly from September 2017 to August 2018. Negative values represent the burnt area and positive values forest areas. Each one of the seven transects were represented for each distance. Lines represent the mean value for each area

Fig. 4 Seed rain results showing seed rain species richness: average seed rain species richness (a), total seed rain species richness (b), average zoochoric seed rain species richness (c), total zoochoric seed rain species richness (d), average non-zoochoric seed rain species richness (e), and total non-zoochoric seed rain species richness (f) recorded in each survey and for the seven transects in burnt and unburnt (forest) areas in the Atlantic Forest, Brazil. Surveys were performed monthly from September 2017 to August 2018. Negative and positive values represent the burnt areas and unburnt areas, respectively. Lines represent the mean value for each area Fig. Zoochoric seed width (a) and non zoochoric seed weight of (b) in burnt and unburnt areas, Una, Bahia, Brazil. In the $\mathrm{x}$-axes, positive and negative values represent unburnt and burnt areas, respectively. The dots and lines represent transects and average values, respectively 


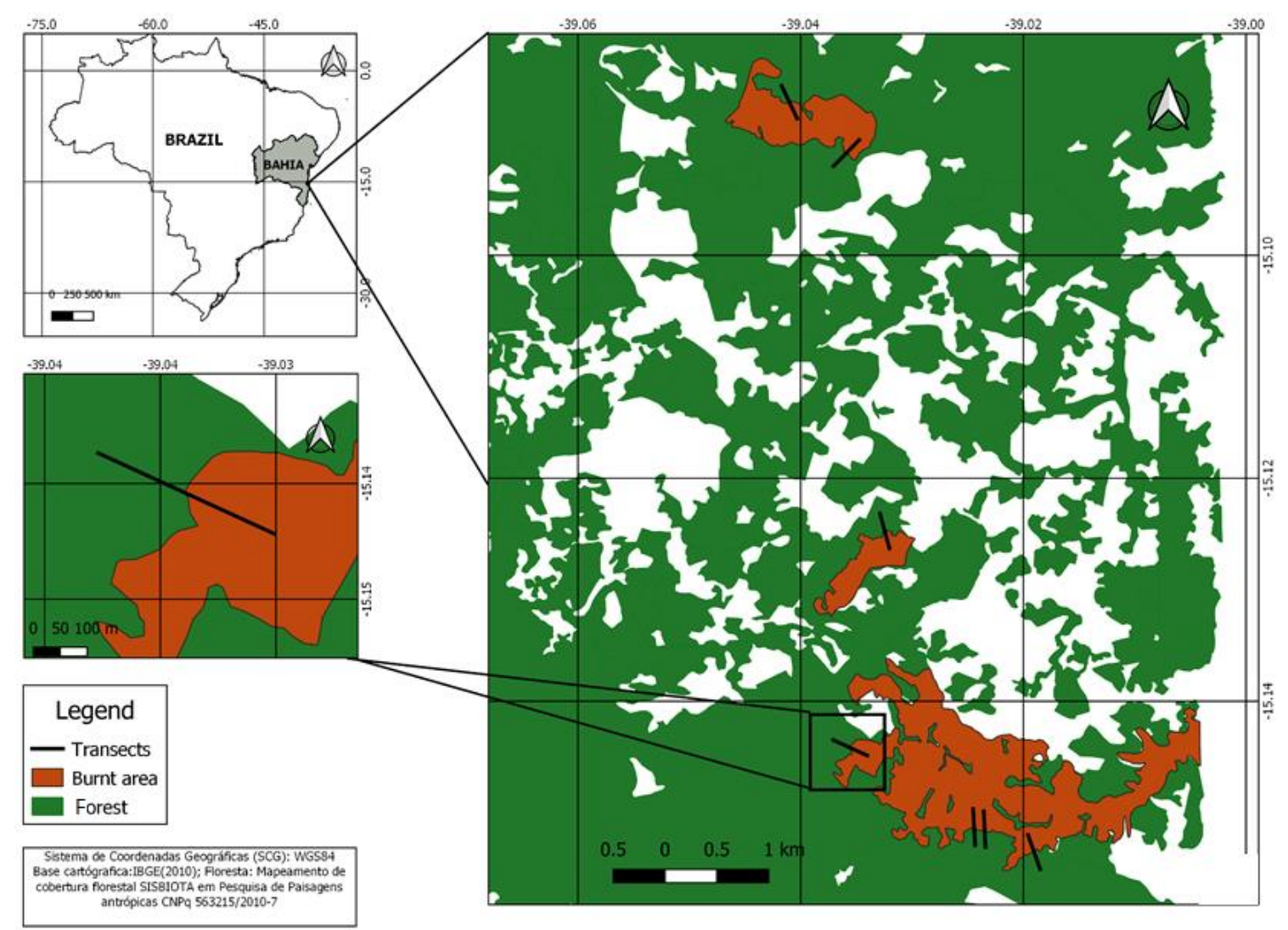


Model

Null

Categorical, edge classified as forest

Categorical, edge classified as burned area

Additive

Additive and Categorical, edge classified as burned area

Additive and Categorical, edge classified as forest
Description

No gradients and no differences between the burned area and the unburned forest.

Mean values differ between the burned area and the unburned forest; edge is similar to the unburned forest.

Mean values differ between the burned area and the unburned forest; edge is similar to the burned area.

Gradual variation in the response variable along the transect.

Gradual variation in the response variable along the transect with additional differences in mean values between the burned and unburned area; edge is similar to the unburned forest.

Gradual variation in the response variables along the transect with additional differences in mean values between the burned forest and the unburned area; edge is similar to the burned area.

\section{Visualization}
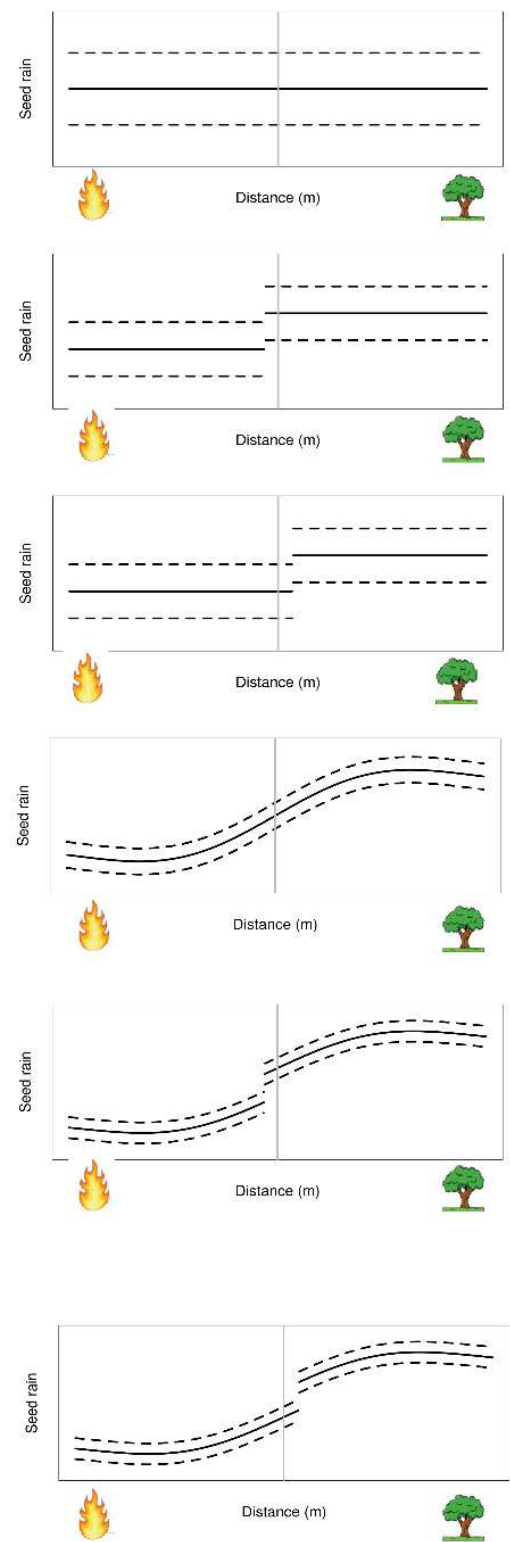

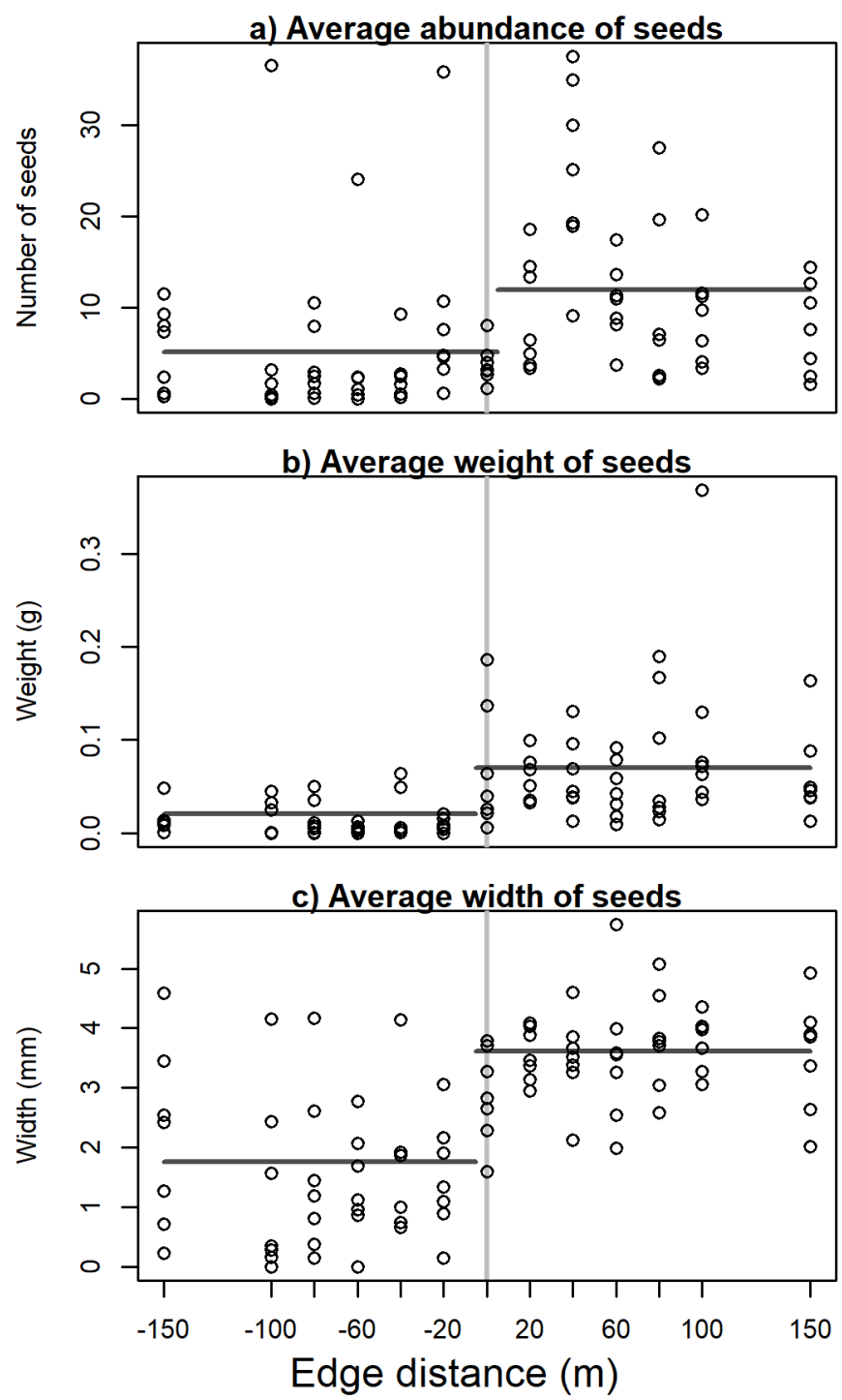

601

602

603

604

605

606

607

608

609

610 

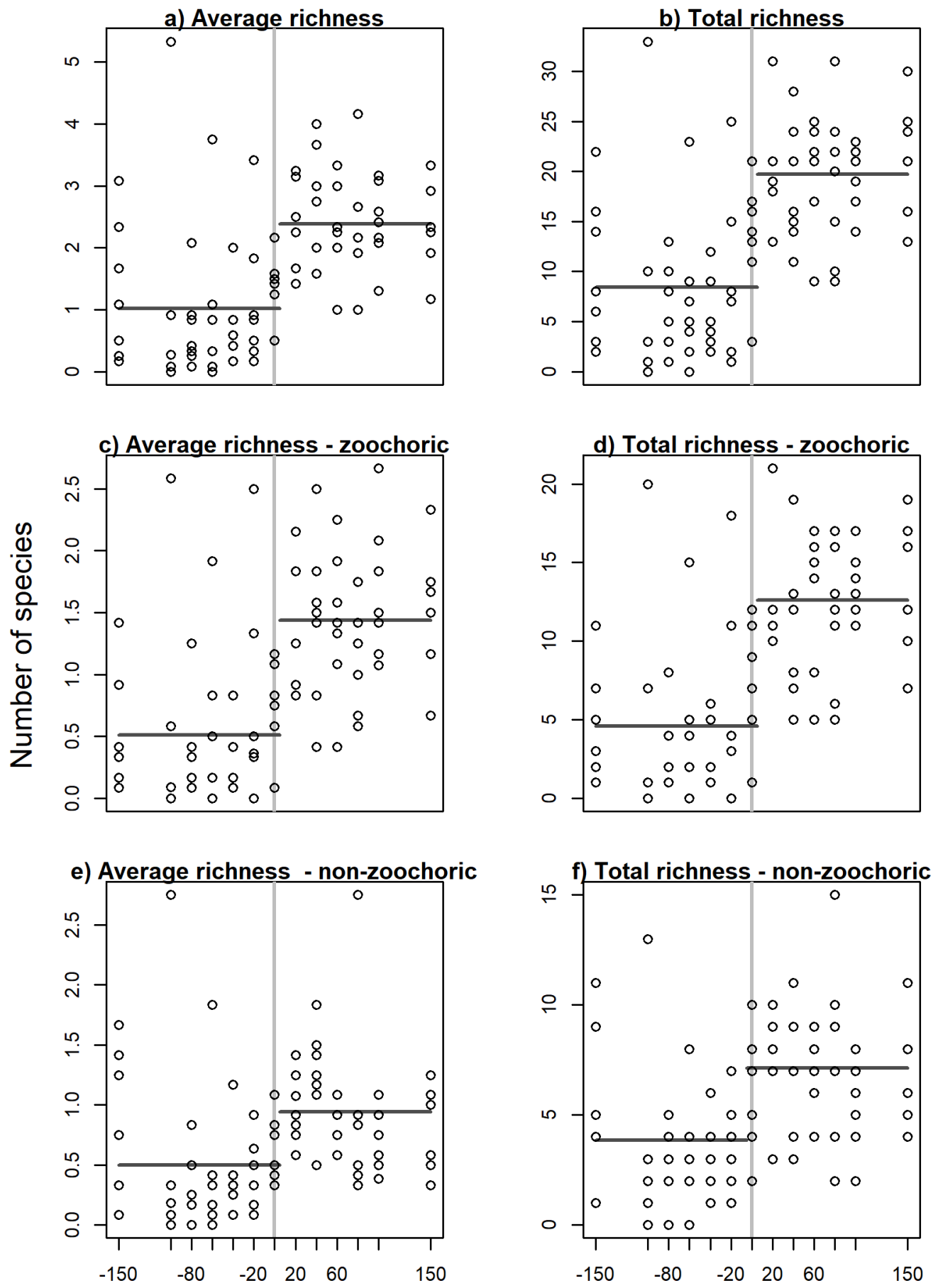

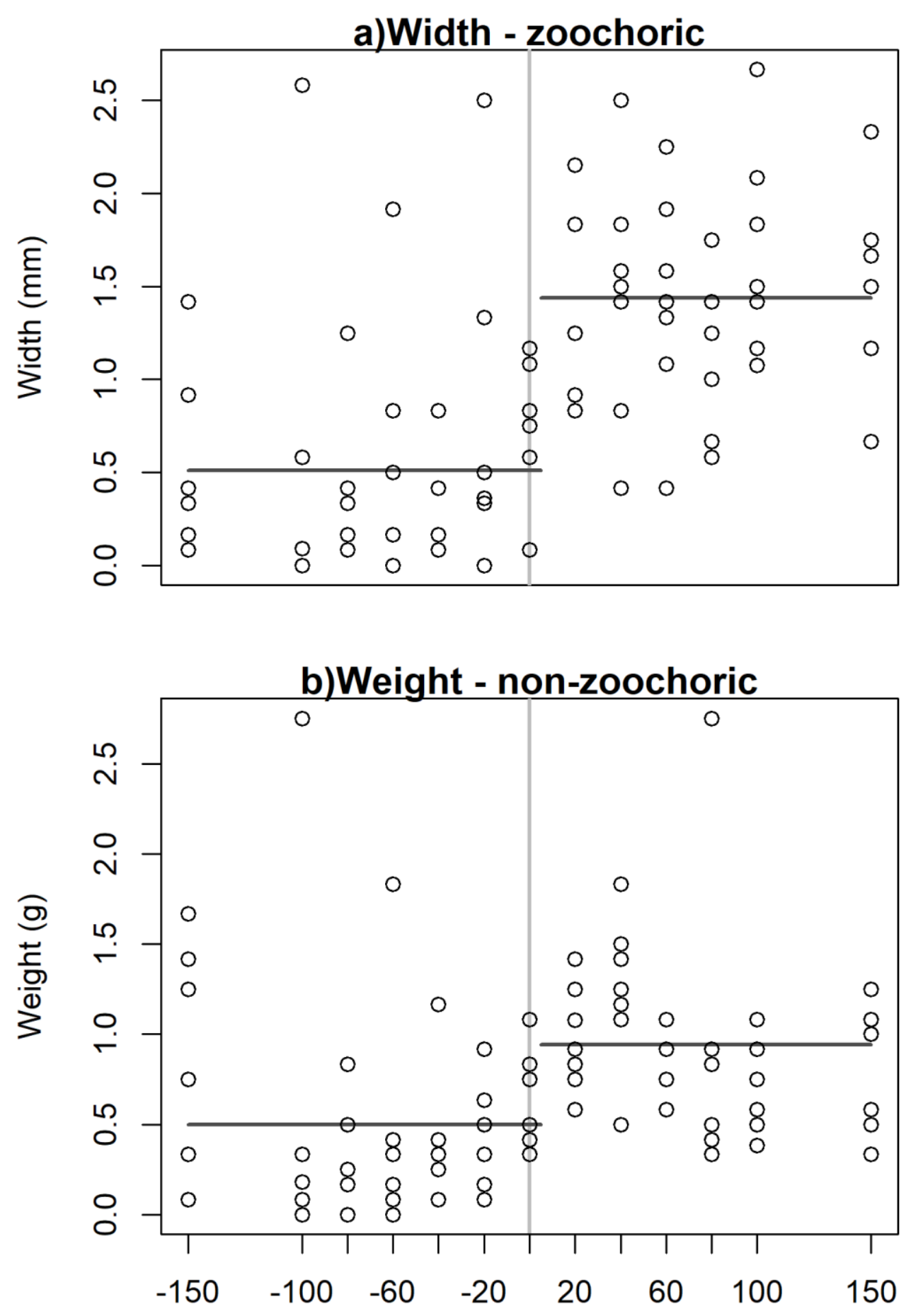

Edge distance (m) 


\section{Bray-Curtis}

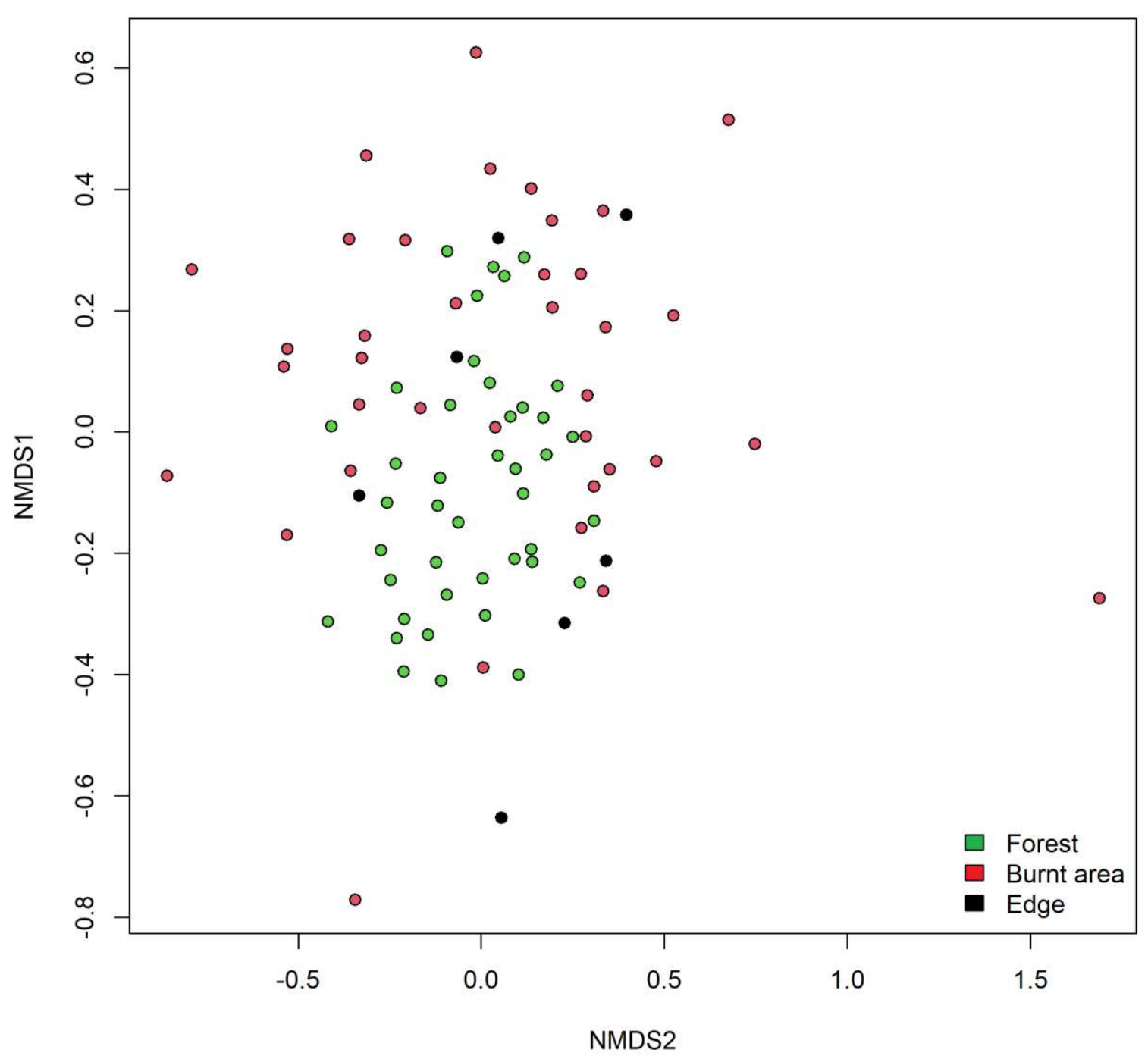

621 